\title{
(2) OPEN ACCESS \\ Budget impact analysis of bevacizumab biosimilars for cancer treatment in adult patients in Spain
}

\author{
Miguel Angel Calleja, ${ }^{1}$ Joan Albanell, 2,3,4,5 Enrique Aranda, 6,7 Jesús García-Foncillas, ${ }^{8}$ \\ Anna Feliu, ${ }^{9}$ Fernando Rivera, ${ }^{10,11}$ Itziar Oyagüez (D) , ${ }^{12}$ Laura Salinas-Ortega (1) , ${ }^{12}$ \\ Javier Soto Alvarez ${ }^{13}$
}

\section{${ }^{1}$ Pharmacy, Hospital Universitario Virgen Macarena, Sevilla, Spain ${ }^{2}$ Hospital del Mar-CIBERONC Institute for Medical Research, Barcelona, Spain \\ ${ }^{3}$ IMIM, Barcelona, Spain \\ ${ }^{4}$ Pompeu Fabra University, Barcelona, Spain \\ ${ }^{5} \mathrm{HM}$ CIOCC, Barcelona, Spain ${ }^{6} \mathrm{IMIBIC}$, Cordoba, Spain ${ }^{7}$ Hospital Universitario Reina Sofía-CIBERONC, Cordoba Spain \\ ${ }^{8}$ Hospital Universitario Fundacion Jimenez Diaz, Madrid, Spain \\ ${ }^{9}$ Hospital de la Santa Creu i Sant Pau, Barcelona, Spain ${ }^{10}$ Hospital Universitario Marqués de Valdecilla, Cantabria, Spain \\ ${ }^{11}$ IDIVAL, Cantabria, Spain ${ }^{12}$ Pharmacoeconomics and Outcomes Research Iberia, Madrid, Spain \\ ${ }^{13}$ HEOR, Pfizer Spain, \\ Alcobendas, Spain}

\section{Correspondence to}

Laura Salinas-Ortega, Pharmacoeconomics and Outcomes Research Iberia, Pozuelo de Alarcón 28224, Spain; Isalinas@porib.com

Received 8 July 2021 Accepted 1 November 2021

EAHP Statement 6: Education and Research.

\section{ABSTRACT \\ Objective To assess the economic impact of introducing biosimilars of bevacizumab for the management of cancer patients receiving systemic bevacizumab in the National Health System (SNHS) of Spain.}

Methods A 3-year budget impact analysis model was adapted to estimate the cost of introducing biosimilars of bevacizumab in the SNHS for the adult population who were candidates to receive treatment with bevacizumab. Values for the estimation of the population were obtained from the literature and were validated by an expert panel. In this analysis only pharmaceutical costs ( $€$, year 2021) obtained from official databases were considered. A sensitivity analysis was performed to examine the robustness of the model.

Results The introduction of bevacizumab biosimilars would generate an annual cost saving of $€ 11558268$ $(-5.1 \%)$ for the first year with a penetration share of biosimilars from 30.0\%, €29 $126373(-8.5 \%)$ for the second year with a share of $50.0 \%$ and $€ 52361778$ $(-13.6 \%)$ for the third year with a share of $80.0 \%$. The total pharmaceutical costs of the scenario without biosimilars are $€ 227033352$ for the first year, €342 663209 for the second year and $€ 385013076$ for the third year. In contrast, the pharmaceutical costs of the scenario with bevacizumab biosimilars are $€ 215475$ 084, €313536 836 and €332 651297 for years 1, 2 and 3 , respectively.

Conclusions The introduction of biosimilars in the Spanish Health System would generate saving costs in the pharmacological budget to boost biological drugs from the first year.

\section{INTRODUCTION}

Cancer is the second leading cause of death in Europe and one of the diseases with the greatest impact on public health. ${ }^{1}$ Advances in the knowledge of tumour biology in recent years have allowed the development of new systemic therapies based on the use of biological agents, whose purpose is to modify or enhance the patient's immune defence against the tumour. ${ }^{1}$ Unlike conventional chemotherapeutic agents, biological agents have a more selective antitumor action, such as the ability to interfere with tumour cell angiogenesis, which causes a decrease in tumour growth. ${ }^{1}$

Bevacizumab was the first approved angiogenesis inhibitor and thus expanded the line of biological treatments against cancer. ${ }^{2}$ It is a monoclonal antibody that acts as an inhibitor of vascular endothelial growth factor, whose main function is the formation of new blood vessels and promoting the maturation of dendritic cells, which can increase the infiltration of $\mathrm{T}$ cells to create a tumour-permissive immune microenvironment. ${ }^{34}$

It is estimated that, in Europe, approximately $30 \%$ of the pharmaceutical budget is allocated to the acquisition of biological drugs, and it is expected that this percentage will increase in coming years. ${ }^{5}$ The expiration of patents for the originator biological drugs has given rise to biosimilar drugs as alternatives, which has allowed health systems to reduce their pharmaceutical expenditures without reducing the available therapeutic options. ${ }^{6}$

The bevacizumab biosimilars Zirabev (Pfizer), MVASI (Amgen) and Aybintio (MSD) have clinical profiles similar to that of the originator bevacizumab in terms of safety and efficacy. ${ }^{2-4} 7$ They have also been approved by the European Medicines Agency (EMA) and the Spanish Agency of Medicines and Medical Products (AEMPS) for the treatment of adult patients, either alone or in combination with other chemotherapeutic agents for metastatic colorectal cancer (mCRC); metastatic breast cancer $(\mathrm{mBC})$; metastatic, unresectable or relapsed non-small cell lung cancer (mNSCLC), except for squamous cell histological type; advanced and/or metastatic renal cell carcinoma (mRCC); stage IIIB, IIIC and IV epithelial ovarian, Fallopian tube or peritoneal cancer (mOC); and persistent, recurrent or metastatic cervical cancer (mCC). ${ }^{2-47}$

The global economic crisis, which has increased as a result of the pandemic caused by SARS-CoV-2, has highlighted the relevance of incorporating economic criteria into healthcare decision-making to increase the efficiency of health systems. ${ }^{89}$

Budget impact analysis (BIA) is a type of economic evaluation that allows the financial implications of the introduction and use of new alternatives for the treatment of a particular disease to be estimated, and its results are an additional tool to consider in the decision-making process. ${ }^{10}$

The objective of the present analysis is to determine the economic impact on the Spanish Health System (SNHS) of including bevacizumab biosimilars in the systemic treatment of patients with cancer.

\section{METHODS}

For the BIA, Microsoft Excel was used to develop a model that estimates the financial impact of the use of bevacizumab biosimilars in patients with cancer in Spain by comparing two different scenarios: 


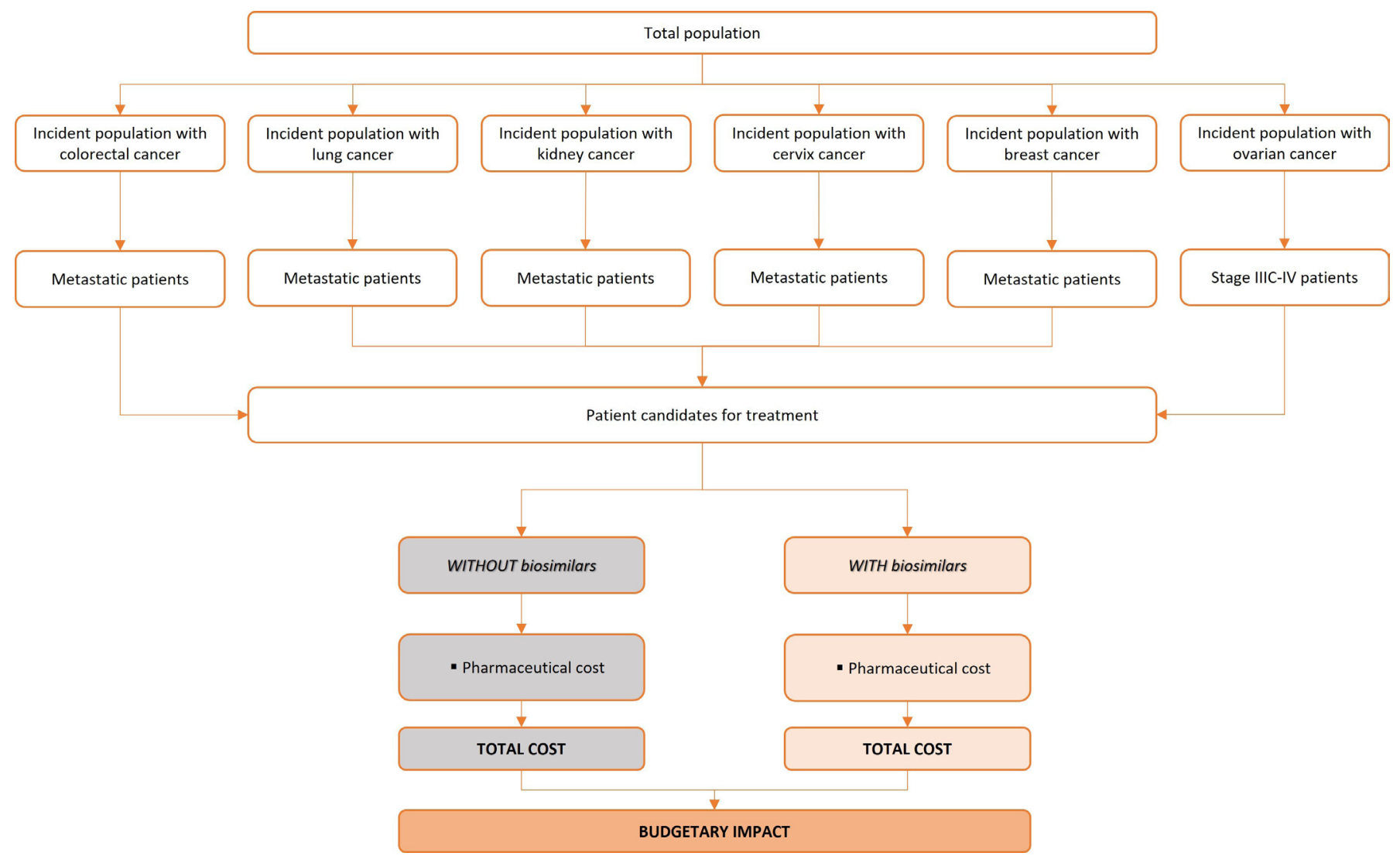

Figure 1 Structure of budget impact analysis (BIA) model.

a scenario without the availability of bevacizumab biosimilars in which only bevacizumab (Avastin, Roche) is available and a scenario with the availability of bevacizumab biosimilars (figure 1).

All the parameters used to feed the model were extracted from the literature and validated by a panel of seven experts (oncologists and hospital pharmacists) based in clinical practice in Spain.

\section{Therapeutic alternatives}

The therapeutic alternatives considered in the model were bevacizumab and bevacizumab biosimilars (Zirabev, MVASI and Aybintio).

In line with the indications authorised by and included in the healthcare system's financing scheme, the present analysis included the use of bevacizumab in adult patients for the indications described in table 1.

Both bevacizumab and its biosimilars are administered intravenously according to specified cycle lengths or until disease progression.

\section{Population}

The population considered in the analysis included patients with some of the tumours that can be treated with bevacizumab based on the total population at the national level reported by the National Institute of Statistics corresponding to the adult Spanish population on 1 January 2020 (39006 054 adults), except for cancers that affect only or mainly females (mCC, $\mathrm{mBC}$ and $\mathrm{mOC}$ ), for which a total of 20099852 adult women was considered $^{11}$ (table 1 ).

The incidence rates of the different cancer entities were obtained from data published by the Spanish Network of Cancer Registries (REDECAN) for 2020. ${ }^{12}$ Of these parameters, data on advanced or metastatic disease, the proportion of patients treated per line and the proportion of patients eligible to receive bevacizumab according to the summary of products characteristics (SmPC) were applied (table 1, figure 1).

\section{Time horizon and discount rate}

In accordance with the perspective, only the pharmaceutical costs of the acquisition of bevacizumab were considered in the model. The cost of intravenous administration was not included because it is the same for all drugs.

The time horizon established for the BIA was 3 years, between 2021 and 2023. No discount rate was considered, as recommended in the BIA best practices guidelines of the International Society for Pharmacoeconomics and Outcomes Research. ${ }^{10}$

\section{Resources and costs}

The acquisition costs were calculated based on the dosages established in the SmPC (table 1). Because bevacizumab is administered according to patient weight, a standard average weight of $70 \mathrm{~kg}$ was established for both men and women. ${ }^{13}$

The analysis was calculated based on the ex-factory prices, which were obtained from the database of the General Council of Official Colleges of Pharmacists, ${ }^{14}$ after applying the mandatory deductions. ${ }^{15}$ The ex-factory price of original bevacizumab was $€ 316.08$ (100 $\mathrm{mg})$ and the ex-factory price of biosimilars was €262.43 (100 mg).

Estimation of the pharmaceutical cost for each cancer considered the duration of treatment for each case, which was obtained from the literature $e^{1617}$ and validated by the expert panel. For the treatment durations of $\mathrm{mCRC}$ and $\mathrm{mCC}$, an average was calculated based on the durations of each treatment line and 
Table 1 Indication, posology and parameters used to obtain the flow of patients according to indication

\begin{tabular}{|c|c|c|c|c|c|c|}
\hline Neoplasm & $\mathrm{mCRC}$ & $\mathrm{mBC}$ & mNSCLC & $\mathrm{mRCC}$ & $\mathrm{mOC}$ & $\mathrm{mCC}$ \\
\hline Indication & $\begin{array}{l}\text { In combination with } \\
\text { fluoropyrimidine-based } \\
\text { chemotherapy }\end{array}$ & $\begin{array}{l}\text { In combination with first-line } \\
\text { paclitaxel. } \\
\text { In combination with } \\
\text { capecitabine as first-line } \\
\text { or as an alternative to } \\
\text { treatment with taxanes } \\
\text { or anthracyclines. Patients } \\
\text { who have treatment with } \\
\text { bevacizumab in combination } \\
\text { with capecitabine in the last } \\
12 \text { months must be excluded }\end{array}$ & $\begin{array}{l}\text { In combination with } \\
\text { first-line platinum-based } \\
\text { chemotherapy and in } \\
\text { combination with first line, } \\
\text { except in patients with } \\
\text { squamous cells. } \\
\text { In combination with erlotinib } \\
\text { in patients with activating } \\
\text { mutations in epidermal } \\
\text { growth factor receptor }\end{array}$ & $\begin{array}{l}\text { In combination with } \\
\text { first-line interferon } \\
\alpha-2 a\end{array}$ & $\begin{array}{l}\text { In combination with first-line } \\
\text { carboplatin and paclitaxel in } \\
\text { patients with advanced cancer } \\
\text { (stages IIIB, IIIC and IV). } \\
\text { In combination with carboplatin } \\
\text { and gemcitabine (during 6-10 } \\
\text { cycles) or in combination with } \\
\text { carboplatin and paclitaxel (during } \\
6-8 \text { cycles) in patients sensitive } \\
\text { to platinum after first relapse } \\
\text { who have not received a previous } \\
\text { treatment of bevacizumab or VEGF } \\
\text { inhibitors. } \\
\text { In combination with paclitaxel, } \\
\text { topotecan or liposomal pegylated } \\
\text { doxorubicin in patients resistant } \\
\text { to platinum after relapse and } \\
\text { who have not received more } \\
\text { than two previous treatments of } \\
\text { bevacizumab or VEGF inhibitors }\end{array}$ & $\begin{array}{l}\text { In combination } \\
\text { with paclitaxel and } \\
\text { cisplatin or paclitaxel } \\
\text { and topotecan in } \\
\text { patients who cannot } \\
\text { tolerate platinum } \\
\text { therapy }\end{array}$ \\
\hline Posology (mg/kg) & $\begin{array}{l}5 \mathrm{mg} / \mathrm{kg} \text { every } 2 \text { weeks } \\
\text { (with Folfox and Folfiri)* }^{*} \\
7.5 \mathrm{mg} / \mathrm{kg} \text { every } 3 \\
\text { weeks (with CAPOX or } \\
\text { capecitabine)* }\end{array}$ & $10 \mathrm{mg} / \mathrm{kg}$ every 2 weeks & $15 \mathrm{mg} / \mathrm{kg}$ every 3 weeks & $10 \mathrm{mg} / \mathrm{kg}$ every 2 weeks & $\begin{array}{l}7.5 \mathrm{mg} / \mathrm{kg} \text { every } 3 \text { weeks } \\
15 \mathrm{mg} / \mathrm{kg} \text { every } 3 \text { weekst }\end{array}$ & $\begin{array}{l}15 \mathrm{mg} / \mathrm{kg} \text { every } 3 \\
\text { weeks }\end{array}$ \\
\hline $\begin{array}{l}\text { Treatment duration } \\
\text { (months) }\end{array}$ & $9 \ddagger$ & $6^{23}$ & $6^{16}$ & $8.5^{17}$ & $8 \S$ & $4.7 \ddagger^{1920}$ \\
\hline Base population $^{11}$ & 39006054 & 20099852 & 39006054 & 39006054 & 20099852 & 20099852 \\
\hline $\begin{array}{l}\text { Crude incidence rate } \\
(100000 \text { person-year })^{12}\end{array}$ & 113.40 & 163.95 & 75.98 & 18.72 & 18.13 & 9.81 \\
\hline Histology with indication & NA & Triple negative (15.0\%) $\rrbracket^{24}$ & $\begin{array}{l}\text { Non-microcytic }(85.0 \%)^{25} \\
\text { Adenocarcinoma }(63.8 \%)^{26}\end{array}$ & $\begin{array}{l}\text { Renal cell carcinoma } \\
(85.0 \%)^{27}\end{array}$ & Epithelial ovarian $(90.0 \%)^{28}$ & NA \\
\hline$\%$ metastatic & $50.0 \%{ }^{29}$ & $30.0 \%{ }^{23}$ & $70.0 \%^{30}$ & $55.0 \%{ }^{31}$ & Stage IIIC-IV (55.0\%)§ & $30.0 \%{ }^{32}$ \\
\hline $\begin{array}{l}\% \text { first-line systemic } \\
\text { treatment }\end{array}$ & NA & $94.0 \% \S$ & $80.0 \%^{30}$ & $90.0 \% \S$ & $90.0 \% \S$ & $90.0 \% \S$ \\
\hline $\begin{array}{l}\% \text { second-line systemic } \\
\text { treatment }\end{array}$ & NA & NA & NA & NA & $70.0 \% \S$ & $70.0 \% \S$ \\
\hline $\begin{array}{l}\% \text { third-line systemic } \\
\text { treatment }\end{array}$ & NA & NA & NA & NA & $50.0 \% \S$ & NA \\
\hline $\begin{array}{l}\% \text { treatment patients with } \\
\text { bevacizumab }\end{array}$ & $25.6 \%^{18}$ & $30.0 \% \S$ & $5.0 \% \S$ & $1.0 \% \S$ & $60.0 \% \S$ & $20.0 \% \S$ \\
\hline $\begin{array}{l}\text { Total no of patients who } \\
\text { received bevacizumab }\end{array}$ & 5653 & 308 & 450 & 31 & 1997 & 181 \\
\hline
\end{tabular}

*The Advisory Board determined that $20.0 \%$ of patients received $5 \mathrm{mg} / \mathrm{kg}$ Folfox and Folfiri and $80.0 \%$ received CAPOX or capecitabine.

†The Advisory Board determined that $20.0 \%$ of patients received a dose of $15 \mathrm{mg} / \mathrm{kg}$ every 3 weeks and $80.0 \%$ received a dose of $7.5 \mathrm{~kg} / \mathrm{mg}$ every 3 weeks.

‡The duration was calculated based on posology and the mean durations of all lines.

$\S$ Advisory Board value.

१Only the triple negatives have been considered for this analysis.

mBC, metastatic breast cancer; mCC, metastatic cervical cancer; mCRC, metastatic colorectal cancer; mNSCLC, metastatic, unresecable or relapsed non-small cell lung cancer; mOC, metastatic epithelial ovarian,

fallopian tube or peritoneal cancer.; mRCC, metastatic renal cell carcinoma; NA, not available; VEGF, vascular endothelial growth factor.

the proportion of patients who were treated in each line ${ }^{18-20}$ (table 1).

All costs are expressed in euros for the year 2021 (€, 2021).

\section{Estimation of bevacizumab biosimilar use}

The incorporation of bevacizumab biosimilars into the SNHS will change the proportions of use of bevacizumab and its biosimilars over the years. Based on the experts' experience, the estimated biosimilar penetration proportions were $30.0 \%$ in the first year, $50.0 \%$ in the second year and $80.0 \%$ in the third year.

No difference in use was established among the bevacizumab biosimilars, assuming that their ex-factory prices are equal and would not affect the results of the BIA.

\section{Sensitivity analysis}

To check the robustness of the model, a sensitivity analysis (SA) was performed by analysing different scenarios in which the values of the following parameters were changed: the estimated use of bevacizumab biosimilars in the different analysis years (SA1, SA2 and SA3) and the ex-factory price of both bevacizumab and bevacizumab biosimilars. For the latter analysis, scenarios were proposed in which price reductions of 20.0\% (SA4), 30.0\% (SA5) and $40.0 \%$ (SA6) were applied to all alternatives and both scenarios.

In addition, the price of original bevacizumab was compared with the price of bevacizumab biosimilars in the scenario with biosimilars (SA7).

Lastly, an analysis was performed in which the difference in ex-factory prices between original bevacizumab and bevacizumab biosimilars was changed (SA8).

\section{RESULTS}

After applying epidemiological data, it was estimated that the total number of current patients who are candidates for treatment with bevacizumab would be 7004, 10622 and 11973 over the 3 -year study period. The indication with the greatest number of candidates receiving bevacizumab was mCRC (5653 patients), and the one with the fewest recipients was mRCC (31 patients) (table 1). 
The introduction of bevacizumab biosimilars at the estimated shares would equate to the treatment of 2100 patients with biosimilar bevacizumab in the first year, 5311 in the second year and 9579 in the third year, as shown in table 2.

Figure 2 shows the pharmaceutical acquisition drug cost per patient per year for each of the cancers treated with bevacizumab. The cost of mNSCLC without biosimilars is €57 687 compared with $€ 47948$ with biosimilars. In contrast, mCRC has a pharmaceutical cost per patient of $€ 29207$ per year without biosimilars compared with $€ 24245$ with biosimilars. These neoplasms generated cost differences of $€ 9740$ for mNSCLC and $€ 4963$ for mCRC.

The total pharmaceutical costs without biosimilars are $€ 227033352$ for the first year, €342663209 for the second year and $€ 385013076$ for the third year. In contrast, the acquisition drug costs of the scenario with bevacizumab biosimilars are $€ 215475084, € 313536836$ and $€ 332651297$ for years 1, 2 and 3, respectively. This results in a decrease in the budgetary impact of $5.1 \%$ in the first year, $8.5 \%$ in the second year and up to $13.6 \%$ in the third year after the introduction of biosimilars (table 2).

\section{Sensitivity analysis}

The SA confirmed the results obtained in the base case (table 3). The savings generated by biosimilars ranged from $€ 15411024$ for the first year assuming 40\% use of biosimilars, to $€ 21190$ 158 assuming 55\% use of biosimilars. In the third year, at which point it is assumed that the use of biosimilars in the hospital environment will have stabilised at its maximum, savings could range between $€ 55634389$ at a share of $85.0 \%$ and $€ 63376617$ at a share of $97.0 \%$.

In the analysis that raised the possibility of ex-factory price matching between original bevacizumab and its biosimilars, the cumulative savings for the Spanish SNHS in the 3 years of analysis would be up to $€ 162014225$ (17.0\%) compared with the current situation with bevacizumab.

Taking into account the existence of trade agreements involving variations in the prices for both alternatives, an analysis was performed in which the difference between both ex-factory prices was varied (figure 3 ). The cumulative savings percentage over 3 years would increase as the price difference between the ex-factory prices increased as a result of greater reductions in the price of bevacizumab biosimilars.

\section{DISCUSSION}

The present analysis was conducted to estimate the financial impact of the introduction of bevacizumab biosimilars in the Spanish healthcare setting for the treatment of oncological patients who are candidates for treatment with bevacizumab, showing the pharmacological savings resulting from their use.

The cancers associated with the highest use of bevacizumab were mCRC (5653 treated patients) and mOC (1997 treated patients), due in large part to the number of treatment lines for which bevacizumab is indicated. This contrasts with other cancers, such as mRCC, for which almost no patients in Spain are indicated for bevacizumab treatment.

One of the limitations of the analysis was the absence of certain data in the literature that are necessary for estimating populations who are candidates for treatment with bevacizumab. It was therefore necessary to make certain assumptions; however, these assumptions were validated by the participating experts.

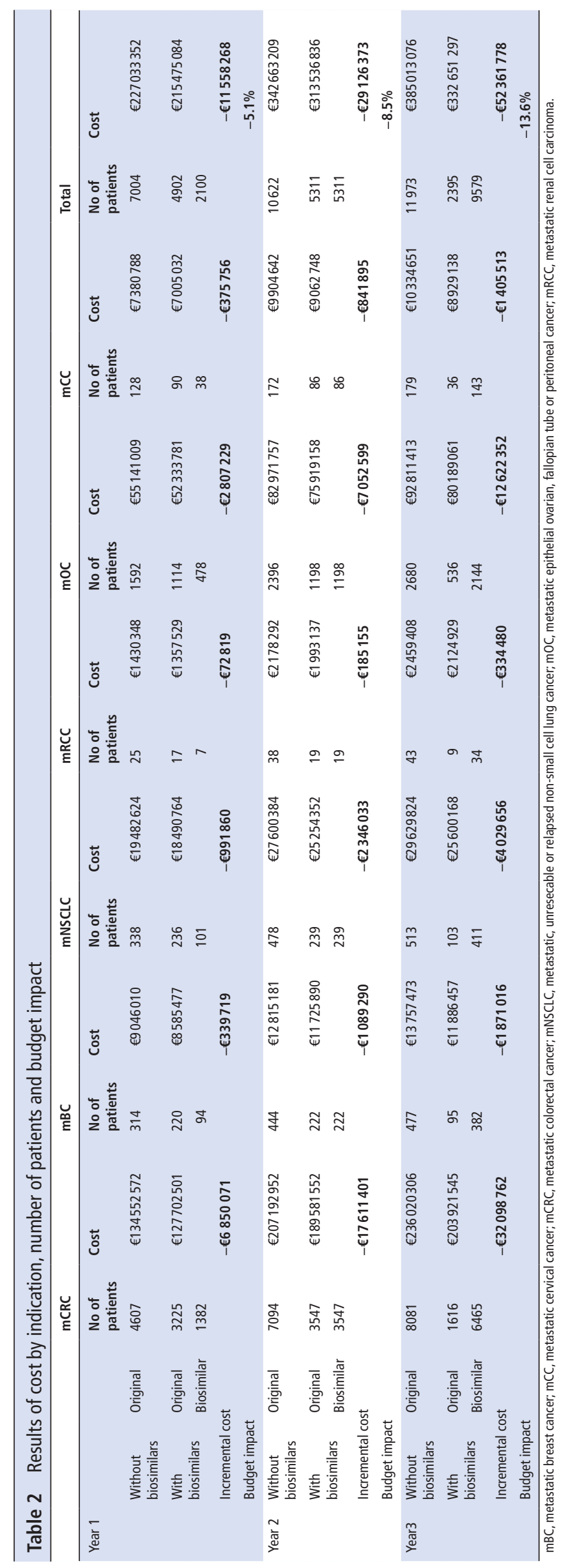




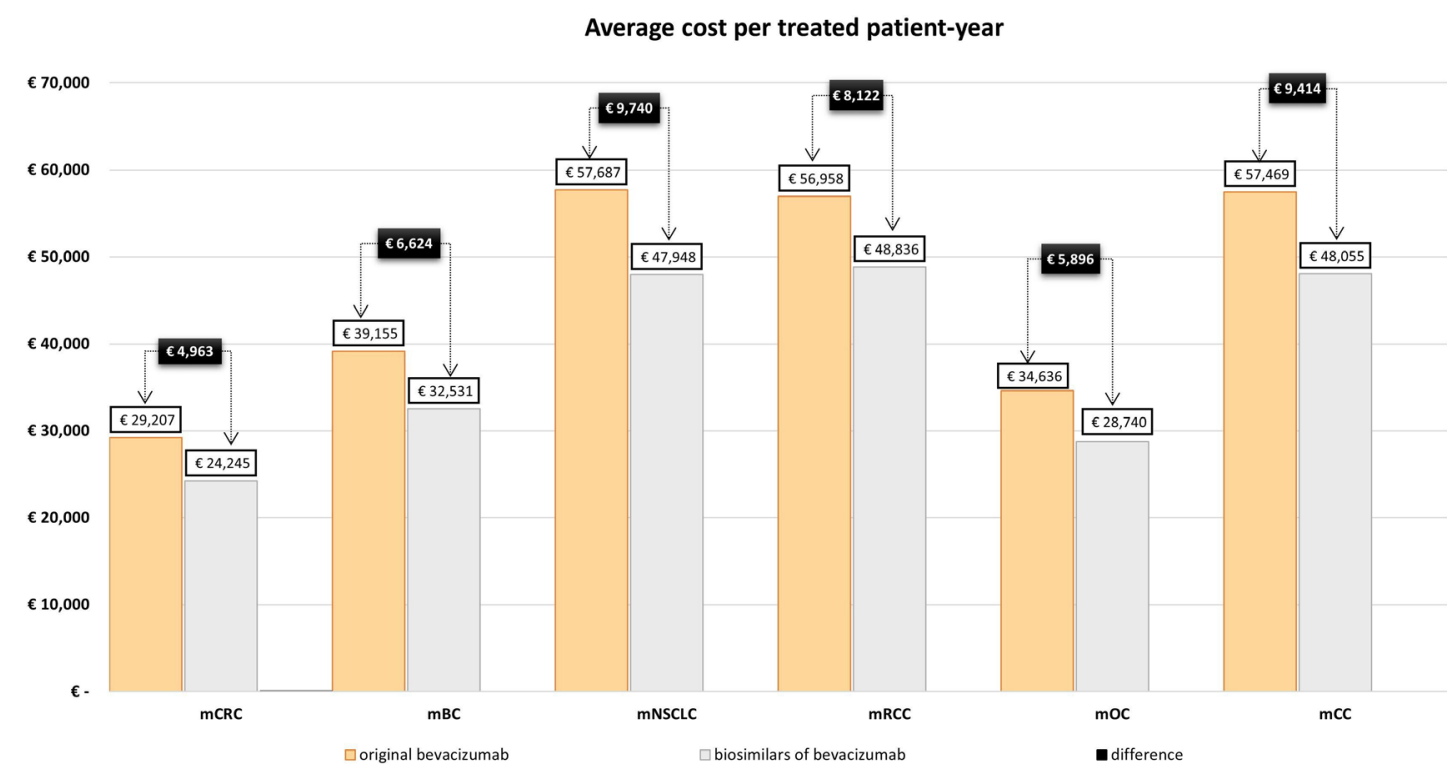

Figure 2 Average cost for patients treated with original bevacizumab versus biosimilar for different indications. $\mathrm{mCRC}$, metastatic colorectal cancer; $\mathrm{mCC}$, metastatic cervical cancer; $\mathrm{mBC}$, metastatic breast cancer; mNSCLC, metastatic, unresecable or relapsed non-small cell lung cancer; mRCC, metastatic renal cell carcinoma; $\mathrm{mOC}$, metastatic epithelial ovarian, fallopian tube or peritoneal cancer.

Regarding pharmaceutical costs per patient, a decrease in the costs of all cancers treated with bevacizumab was observed after the introduction of biosimilars. This finding results from two factors. On the one hand, for indications that required higher doses there was a greater impact due to the lower price of biosimilars compared with bevacizumab; this phenomenon was observed for indications such as mNSCLC and mRCC. On the other hand, indications for which a greater number of patients are candidates for treatment with either bevacizumab or its biosimilars, such as mOC and mCRC, showed high cost differences.

It is therefore clear that the use of biosimilars can generate certain savings in the treatment of patients with cancer. The analysis suggests that, for some indications, these savings may be approximately $€ 9500$ per treated patient-year. Even for indications with a lower cost difference between the scenarios such as mCRC, biosimilars can save $€ 4900$ per patient-year, which translates into a decrease in the pharmacological budget due to the large number of patients who can benefit from the use of biosimilars.
Nonetheless, these data are not free from possible bias since the yearly pharmaceutical cost was calculated by estimating the duration of treatment by indication. Because of this limitation of the model, it was not possible to calculate the pharmaceutical cost per line for each of the indications.

In breast cancer, the main use of bevacizumab is in triple negative patients and we focused the current analysis in this population. However, bevacizumab is also approved by EMA for patients with $\mathrm{HR}+/ \mathrm{HER} 2$ - advanced breast cancer after exhausting hormone therapy options or in patients with visceral crisis. However, due to the lower use in these patients and the difficulties in obtaining an accurate estimation of the proportion of affected persons, this was not included in the calculations. Furthermore, the EMA approval of atezolizumab and nabpaclitaxel in PD-L1+ metastatic triple negative patients, which account for $40 \%$ of the cases, might also change the current estimations of the impact of bevacizumab biosimilars in breast cancer in the near future.

With these limitations in mind, the results of this analysis showed the impact on the budget. In the first year, and with

Table 3 Sensitivity analysis

\begin{tabular}{|c|c|c|c|c|c|c|c|c|}
\hline \multirow[b]{2}{*}{ Parameters } & \multirow[b]{2}{*}{ Value } & & \multicolumn{2}{|l|}{ Year 1} & \multicolumn{2}{|l|}{ Year 2} & \multicolumn{2}{|l|}{ Year 3} \\
\hline & & & $\begin{array}{l}\text { Difference scenario } \\
\text { with vs without }\end{array}$ & $\%$ & $\begin{array}{l}\text { Difference scenario with } \\
\text { vs without }\end{array}$ & $\%$ & $\begin{array}{l}\text { Difference scenario } \\
\text { with vs without }\end{array}$ & $\%$ \\
\hline Base case & & & $-€ 11558268$ & $-5.1 \%$ & $-€ 29126373$ & $-8.5 \%$ & $-€ 52361778$ & $-13.6 \%$ \\
\hline \multirow{3}{*}{$\begin{array}{l}\text { Biosimilar shares } \\
\text { (base case 30\%/50\%/80\%) }\end{array}$} & SA1 & $40 \% / 60 \% / 85 \%$ & $-€ 15411024$ & $-6.8 \%$ & $-€ 34951647$ & $-10.2 \%$ & $-€ 55634389$ & $-14.5 \%$ \\
\hline & SA2 & $50 \% / 80 \% / 95 \%$ & $-€ 19263780$ & $-8.5 \%$ & $-€ 46602196$ & $-13.6 \%$ & $-€ 62179612$ & $-16.2 \%$ \\
\hline & SA3 & $55 \% / 85 \% / 97 \%$ & -€21 190158 & $-9.3 \%$ & $-€ 49427455$ & $-14.4 \%$ & $-€ 63376617$ & $-16.5 \%$ \\
\hline \multirow{3}{*}{$\begin{array}{l}\text { Reduction of bevacizumab } \\
\text { original price and biosimilars } \\
\text { (before and after introduction of } \\
\text { biosimilars) }\end{array}$} & SA4 & $-20 \%$ & $-€ 9248549$ & $-5.1 \%$ & $-€ 23264846$ & $-8.5 \%$ & $-€ 41824250$ & $-13.6 \%$ \\
\hline & SA5 & $-30 \%$ & -€8093558 & $-5.1 \%$ & $-€ 20359450$ & $-8.5 \%$ & -€36601091 & $-13.6 \%$ \\
\hline & SA6 & $-40 \%$ & $-€ 6936412$ & $-5.1 \%$ & $-€ 17448634$ & $-8.5 \%$ & -€31 368188 & $-13.6 \%$ \\
\hline $\begin{array}{l}\text { Bevacizumab original ex-factory } \\
\text { price equal to biosimilars ex- } \\
\text { factory prices in scenario with } \\
\text { bevacizumab biosimilars }\end{array}$ & SA7 & $€ 262.43$ & $-€ 38527560$ & $-17.0 \%$ & $-€ 58149947$ & $-17.0 \%$ & -€65 336719 & $-17.0 \%$ \\
\hline
\end{tabular}

SA, Sensitivity analysis. 


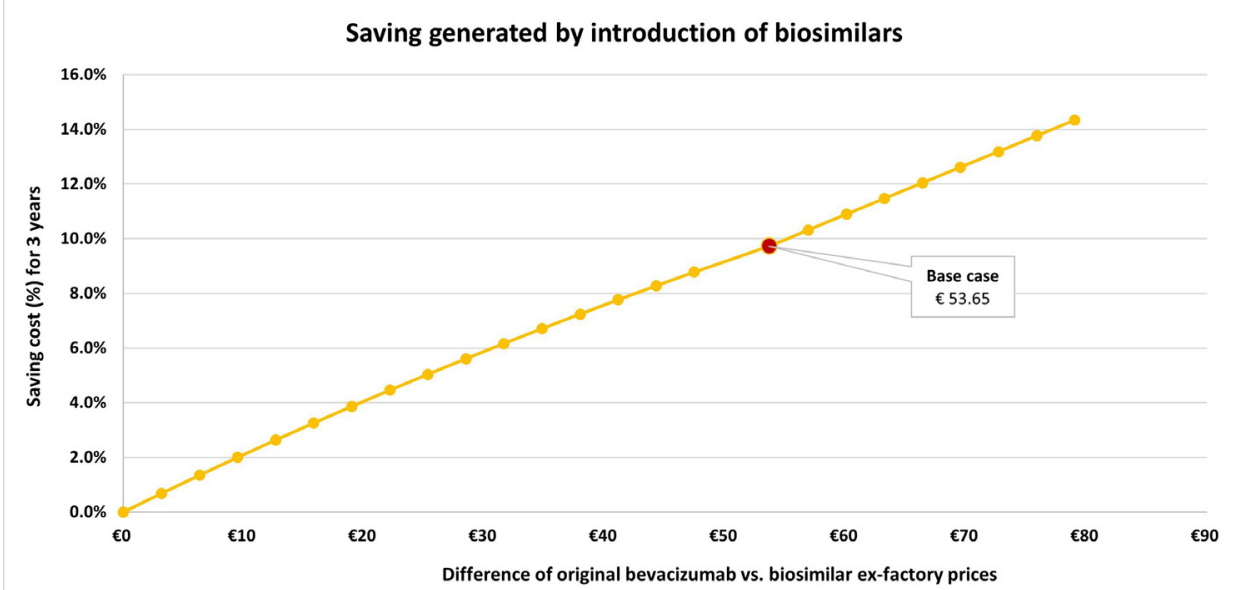

Figure 3 Results of variation in ex-factory prices of original bevacizumab versus biosimilars.

a penetration rate of $30.0 \%$ for the bevacizumab biosimilars, a savings of 5.1\% (-€11 558 268) was estimated. Due to the increase in the market share of bevacizumab biosimilars compared with the original, it was estimated that in years 2 and 3 the budgetary impact would include decreases of $8.5 \%$ $(-€ 29126373)$ and $13.6 \%(-€ 52361778)$, respectively, in the pharmaceutical costs derived from the treatment of oncological patients with bevacizumab. These savings are due to the difference in price between original bevacizumab and its biosimilars and also to the market access policies for biosimilars and the confidence of clinicians in their implementation in the hospital setting, where their demand is greatest. ${ }^{5}$

These savings were based on the listed prices although, in practice, these prices may vary due to decentralised purchasing by hospitals. Therefore, to facilitate the evidence of the savings arising from the introduction of biosimilars, different analyses were performed in which discounts were applied to the prices of both bevacizumab and its biosimilars in the scenarios without and with the availability of biosimilars. Thus, although the percentage of the budgetary impact was equal to that of the base case, the generated savings varied - that is, in the scenario with a $20 \%$ reduction in the ex-factory prices the savings generated for the first year were €9 248549 while, in the scenario with a $40 \%$ reduction, the savings were only $€ 6936412$.

It is foreseeable that the penetration rates of bevacizumab in particular and of biosimilars in general could increase in importance over a relatively short period such as 3 years. Therefore, analyses of different scenarios were also performed in which the usage of bevacizumab biosimilars compared with bevacizumab were varied.

In the first scenario, the first- and second-year shares were increased by $10 \%$ and in the third year they were increased by $5 \%$ compared with the base case. Thus, with shares of $40 \%$, $60 \%$ and $85 \%$ for each year, savings of $€ 15411024$ (first-year), $€ 34951647$ (second-year) and $€ 55634389$ (third-year) were seen.

The literature on the budgetary impact of biosimilars in Spain is scarce. A BIA of biosimilar drugs in the SNHS was recently published that included a retrospective analysis (2009-2019) and a prospective study (2020-2022) in which the impact of bevacizumab biosimilars was determined, along with 17 active principles for the hospital setting. ${ }^{5}$ The bevacizumab biosimilars were analysed over a prospective period of 2 years, with savings of $€ 23600000$ with a usage rate of $50 \%$ for the first year and $€ 48600000$ for the second year with a usage rate of $80 \%$.

In accordance with that report, an analysis was performed based on a biosimilar penetration rate of $50 \%$ that increases to $80 \%$ in the second year and to $95 \%$ in the third year. The savings for each year were €19 263780 , €46602196 and €62 179612 .

The obtained results differed somewhat from those of the cited report, mainly due to two limitations. The first is a possible overestimation of the number of patients treated with bevacizumab, as described above. Another possible limitation is related to the price differences used in the two analyses, since the cost of bevacizumab may be subject to certain discounts at the time of purchase by hospitals, which is not reflected in the results.

The availability of biosimilars leads to a regularisation in the reference price of the original drugs, which leads to an equalisation of prices between the original biological drugs and their biosimilars. ${ }^{5}$ Therefore, two analyses were conducted to consider this factor.

In the first case, the price of bevacizumab was equal to that of its biosimilars after the introduction of the biosimilars, which had a budgetary impact of $17 \%$ reflecting the difference in the drug prices. This result showed a savings of $€ 162014225$ for the 3 years, which contrasts with analyses based on the starting price of other biosimilars, which differ by approximately 20-30\% from the price of the original drug. ${ }^{521}$ However, according to estimates using data from Spain, the price difference between biosimilars and their original drugs is on average $19 \% .{ }^{22}$ The savings produced by the price differences are largely due to two situations: (1) the entry of biosimilars allows access to drugs that are less expensive than the original biological but have similar efficacy and safety; and (2) the price of bevacizumab relative to its biosimilars must be adjusted so that it can compete with them. Thus, both scenarios produce a decrease in pharmaceutical expenditures.

Additionally, an analysis was carried out in which the price of the biosimilars was fixed and the margin of difference from the original bevacizumab was varied to determine the budgetary impact based on the differences between the ex-factory prices. This analysis showed that, with a difference in price of only $€ 3.16$ between the original bevacizumab and the biosimilars, savings of $€ 5473135$ could be obtained for the 3 years of the analysis.

These savings will increase as the difference between the prices of the biosimilars and original drug increases, thus increasing the 
competition between them. In contrast, if this competition is not favoured, the savings tend to decrease to the point that the use of biosimilars would mean a budgetary increase.

In conclusion, the inclusion of bevacizumab biosimilars in the Spanish healthcare system will lead to a decrease in budget allocations for the acquisition of biological medicines that will be notable after the first year.

\section{Key messages}

What is already known on this subject?

- Biosimilars have been shown to generate savings for health systems and improve access to biological medicines.

- The impact on the heath budget of biological medicines is growing

- Budgetary impact studies of biosimilars are limited

\section{What this study adds?}

- The introduction of bevacizumab biosimilars can generate cost savings for the national health system in Spain

Contributors 10 and LSO adapted the model, reviewed the scientific literature, performed the analyses and drafted the manuscript. MAC, JA, EA, JGF, AF, FR and IS validated the model structure and the inputs and provided information about the clinical management of cancer patients receiving bevacizumab in Spain. All the authors contributed to interpretation of the results and reviewed and approved the final version of the manuscript. LSO is the guarantor and accepts full responsibility for the work and/or the conduct of the study, had access to the data, and controlled the decision to publish.

Funding This work was supported by Pfizer Spain grant number Pfizer-2020-05.

Competing interests 10 and LSO are employees of Pharmacoeconomics \& Outcomes Research Iberia (PORIB), a consultant company specialising in health technology assessment, which has received financial support from Pfizer to conduct the development of the present work. JS is an employer of Pfizer Spain. MAC has received payment from Amgen, Roche and Samsung Bioepis for educational events and has participated in Advisory Boards for these companies. JA has received payment from Amgen, Roche and MSD and has received support for attending meetings for MSD and Amgen. EA has participated in Advisory Boards for Amgen, Bayer, Merck Serono, Roche and Sanofi. JGF has contracts with Biocartis, Bayer, Janssen, Merck Serono, Roche, Sanofi, Servier and Sysmex and has also received payment for lectures, presentations, speakers bureaus, manuscript writing or educational events, support for attending meetings and consulting fees from AstraZeneca, Biocartis, BMS, Bayer, Celgene, GSK, Janssen, Lilly, Merck Serono, MSD, Novartis, Pfizer, Foundation Medicine, Roche, Sanofi, Servier, Sysmex and tesaro. FR has received payment for lectures, presentations, speakers bureaus, manuscript writing or educational events and support for attending meetings from Amgen, Merck Serono, MSD, BMS, Servier, Roche, Sanofi and Lilly. MAC, JA, EA, JGF, AF and FR have received payment from Pfizer for consultant activities related to validation of the parameters and results. None of them received financial compensation for review and co-authorship of this manuscript. AF declares no conflicts of interest.

Patient consent for publication Not applicable.

Provenance and peer review Not commissioned; externally peer reviewed.

Data availability statement All data relevant to the study are included in the article or uploaded as supplemental information. Not applicable.

Open access This is an open access article distributed in accordance with the Creative Commons Attribution Non Commercial (CC BY-NC 4.0) license, which permits others to distribute, remix, adapt, build upon this work non-commercially, and license their derivative works on different terms, provided the original work is properly cited, an indication of whether changes were made, and the use is noncommercial. See: http://creativecommons.org/licenses/by-nc/4.0/.

\section{ORCID iDs}

tzziar Oyagüez http://orcid.org/0000-0002-3047-6152

Laura Salinas-Ortega http://orcid.org/0000-0002-7066-0659

\section{REFERENCES}

1 Cajaraville G, Carreras MJ, Massó J. Oncología. In: Gamundi Planas MC, ed. Farmacia hospitalaria tomo /l $3^{a}$ ed. Madrid: Sociedad Española de Farmacia Hospitalaria (SEFH), 2002. https://www.sefh.es/biblioteca-virtual.php
2 Agencia Europea de Medicamentos. Ficha técnica de Zirabev $25 \mathrm{mg} / \mathrm{m} /$ concentrado para solución para perfusión. Londres: Agencia Europea de Medicamentos, 2020. https://www.ema.europa.eu/en/documents/product-information/zirabev-epar-productinformation es.pdf

3 Agencia Española de Medicamentos y Productos Sanitarios. Ficha técnica de MVASI 25 mg/m/ concentrado para solución para perfusión. Madrid: Agencia Española de Medicamentos y Productos Sanitarios, 2017. https://cima.aemps.es/cima/pdfs/es/ft/ 1171246001/FT 1171246001.pdf

4 Agencia Española de Medicamentos y Productos Sanitarios. Ficha técnica de Avastin $25 \mathrm{mg} / \mathrm{m} /$ concentrado para solución para perfusión [Internet. Madrid: Agencia Española de Medicamentos y Productos Sanitarios, 2017. https://cima.aemps.es/cima/ pdfs/es/ft/04300001/FT_04300001.pdf

5 García Goñi M, Carcedo D, Villacampa A. Análisis de impacto presupuestario de los medicamentos biosimilares en el Sistema Nacional de Salud de España (2009-2022). Madrid: BioSim Organización Española de Biosimilares, 2020. https://www.biosim.es/ informes/analisis-de-impacto-presupuestario-de-los-medicamentos-biosimilares-en-elsistema-nacional-de-salud-de-espana-2009-2022/

6 Guiu Segura JM, Gilabert Perramon A. Biosimilar drugs: measures to promote their use. Medicamentos biosimilares: medidas para fomentar su uso. Med Clin 2020;154:148

7 Agencia Española de Medicamentos y Productos Sanitarios. Ficha técnica de Aybintio $25 \mathrm{mg} / \mathrm{m} /$ concentrado para solución para perfusión [Internet]. Madrid: Agencia Española de Medicamentos y Productos Sanitarios, 2017. https://cima.aemps.es/cima/ pdfs/es/ft/04300001/FT 04300001.pdf

8 Corregidor-Luna L, Hidalgo-Correas FJ, García-Díaz B. Pharmaceutical management of the COVID-19 pandemic in a mid-size Hospital. Gestión farmacéutica de la pandemia COVID-19 en un Hospital mediano. Farm Hosp 2020;44:11-16

9 Kousi T, Mitsi L-C, Simos J. The early stage of COVID-19 outbreak in Greece: a review of the national response and the socioeconomic impact. Int J Environ Res Public Health 20212021:18:322

10 Sullivan SD, Mauskopf JA, Augustovski F, et al. Budget impact analysis-principles of good practice: report of the ISPOR 2012 Budget Impact Analysis Good Practice II Task Force. Value Health 2014:17:5-14.

11 Instituto Nacional de Estadística. Proyecciones de población 2018-2068. Población residente en España a 1 de enero, por sexo, edad y año. Resultados nacionales. En: INEbase [Internet]. Madrid: Instituto Nacional de Estadística, 2019. http://www.ine. es

12 Red Española de Registros de Cáncer (REDECAN). Estimaciones de la incidencia del cáncer en España 2020. Available: https://redecan.org/

13 Ortega Eslava A, Marín Gil R, Fraga Fuentes MD. Grupo de Evaluación de Novedades, Estandarización e Investigación en Selección de Medicamenteos (GÉNESIS). Guía de evaluación económica e impacto presupuestario en los informes de evaluación de medicamentos. [Internet]. Madrid: Sociedad Española de Farmacia Hospitalaria, 2016. https://gruposdetrabajo.sefh.es/genesis/genesis/Documents/GUIA_EE_IP_GENESISSEFH_19_01_2017.pdf

14 Consejo General de Colegios Oficiales de Farmacéuticos. Base de datos del Conocimiento Sanitario - Bot Plus 2.0 [Internet]. Madrid: Consejo General de Colegios Oficiales de Farmacéuticos, 2019. https://botplusweb.portalfarma.com/

15 Ministerio de Sanidad, Servicios Sociales e Igualdad. Listado de medicamentos afectados por las deducciones del real Decreto-Ley 8/2010 MARZO 2021. Madrid: Ministerio de Sanidad, Servicios Sociales e Igualdad, 2020. https://www.mscbs.gob. es/profesionales/farmacia/pdf/Deducciones_Marzo_2021.pdf

16 Ramalingam SS, Dahlberg SE, Langer CJ, et al. Outcomes for elderly, advanced-stage non small-cell lung cancer patients treated with bevacizumab in combination with carboplatin and paclitaxel: analysis of Eastern Cooperative Oncology Group Trial 4599. J Clin Oncol 2008:26:60-5

17 Rini BI, Halabi S, Rosenberg JE, et al. Phase III trial of bevacizumab plus interferon alfa versus interferon alfa monotherapy in patients with metastatic renal cell carcinoma: final results of CALGB 90206. J Clin Oncol 2010:28:2137-43.

18 Aranda E, Polo E, Camps C, et al. Treatment patterns for metastatic colorectal cancer in Spain. Clin Trans/ Oncol 2020;22:1455-62.

19 Zighelboim I, Wright JD, Gao F, et al. Multicenter phase II trial of topotecan, cisplatin and bevacizumab for recurrent or persistent cervical cancer. Gynecol Oncol 2013;130:64-8.

20 Tinker AV, Fiorino L, O'Dwyer $\mathrm{H}$, et al. Bevacizumab in metastatic, recurrent, or persistent cervical cancer: the BC cancer experience. Int J Gynecol Cancer 2018;28:1592-9.

21 Portal del medicamento. Medicamentos Biosimilares: ¿a qué esperamos? [Internet]. Valladolid: Consejería de Sanidad de Castilla y León, 2018. https://www. saludcastillayleon.es/portalmedicamento/es/terapeutica/ojomarkov/medicamentosbiosimilares-esperamos

22 IQVIA Institute for Human Data Science. Advancing biosimilar sustainability in Europe, 2018. Available: https://www.iqvia.com/-/media/iqvia/pdfs/institutereports/advancingbiosimilar-sustainability-in-europe.pdf

23 GEICAM (Grupo Español de Investigación en Cáncer de Mama). Guía GEICAM de práctica clínica para el Diagnóstico y Tratamiento del Cáncer de Mama Metastásico [Internet]. Madrid: Comuniland S.L, 2015. https://www.geicam.org/wp-content/ uploads/2016/06/GUIA-GEICAM-COMPLETA.pdf 


\section{Original research}

24 Lobbezoo DJA, van Kampen RJW, Voogd AC, et al. Prognosis of metastatic breast cancer subtypes: the hormone receptor/HER2-positive subtype is associated with the most favorable outcome. Breast Cancer Res Treat 2013;141:507-14.

25 Majem M, Juan O, Insa A, et al. SEOM clinical guidelines for the treatment of nonsmall cell lung cancer (2018). Clin Trans/ Oncol 2019;21:3-17.

26 Provencio M, Carcereny E, Rodríguez-Abreu D, et al. Lung cancer in Spain: information from the Thoracic Tumors Registry (TTR study). Trans/ Lung Cancer Res 2019:8:461-75.

27 Lázaro M, Valderrama BP, Suárez C, et al. SEOM clinical guideline for treatment of kidney cancer (2019). Clin Transl Oncol 2020;22:256-69.

28 Ledermann JA, Raja FA, Fotopoulou C, et al. Newly diagnosed and relapsed epithelial ovarian carcinoma: ESMO clinical practice guidelines for diagnosis, treatment and follow-up. Ann Oncol 2013;24(Suppl 6):vi24-32.
29 Mocellin S, Baretta Z, Roqué I Figuls M. Second-line systemic therapy for metastatic colorectal cancer. Cochrane Database Syst Rev 20172017;1:CD006875.

30 Donado JR, Paz-Ares L. OncoSur: Grupo de trabajo oncológico de centros hospitalarios del sur de Madrid. Guía clínica de diagnóstico y tratamiento del cáncer de pulmón [Internet]. Madrid: Fundación Médica Mutua Madrileña, 2007. http://www.seom.org/ seomcms/images/stories/recursos/sociosyprofs/colectivos/grupocooperativo/2006/ oncosur/guia_clinica_oncosur_cancerpulmon.pdf

31 Bernárdez Ferrán B, López Montero E, Duran Piñeiro G. SEFH: Módulo de Cáncer Renal [Internet]. Madrid: Sociedad Española de Farmacia Hospitalaria (SEFH), 2017Cited 2020 oct 16]. Available at. http://formacion.sefh.es/dpc/sefh-cursooncohematologia/modulo_06.pdf

32 Sánchez Lorenzo L. SEOM : Cáncer de cévix En: Sociedad Española de Oncología Médica [Internet]. Madrid: Sociedad Española de Oncología Médica, 2020. https://seom.org 